\title{
Pharmacological and Biochemical Evidence for the Existence of Two Categories of Dopamine Receptor
}

\author{
J.W. Kebabian, M. Beaulieu and Y. Itoh
}

\begin{abstract}
Evidence supporting the validity of the 'two dopamine receptor' hypothesis is presented. The availability of the 'first generation' of selective agonists and antagonists of the D-1 and the D-2 dopamine receptors provides pharmacological support for the hypothesis. The demonstration that stimulation of the D-2 receptor either inhibits or has no effect upon adenylate cyclase activity while stimulation of the D-1 receptor enhances CAMP formation provides biochemical support for the hypothesis. Finally, binding assays demonstrating two affinity states for the D-1 and the D-2 receptors are briefly discussed.
\end{abstract}

RÉSUMÉ: Nous présentons nos évidences en faveur de l'hypothèse des "deux récepteurs dopaminergiques". L'appui pharmacologique provient des agonistes et antagonistes spécifiques aux récepteurs $D_{1}$ et $D_{2}$ de la première génération. Ainsi nous montrons que la stimulation du récepteur $D_{1}$ augmente la formation d'AMP cyclique alors que celle du récepteur $D_{2}$ inhibe ou n'a aucun effet sur l'activité de l'adenylate cyclase. Enfin nous discuttons brièvement des tests de liaison qui démontrent deux états d'affinité pour chacunes des formes de récepteurs.

Can. J. Neurol. Sci. 1984;11:114-117

In 1979, the existence of two categories of dopamine receptor was hypothesized (Kebabian and Calne, 1979). This 'two dopamine receptor' hypothesis was formulated in an attempt to account for the unanticipated observation that two ergots, lisuride and lergotrile, mimicking the action of dopamine upon the anterior pituitary gland blocked the stimulatory effect of dopamine upon adenylate cyclase activity of homogenates of the caudate nucleus of the rat brain (Kebabian et al., 1977; Pieri et al., 1978). Table 1 presents a summary of the salient features of this hypothesis as it was put forward in 1979. In addition to the aforementioned ergots, only a limited number of drugs discriminated between the two categories of dopamine receptor. An additional difference between the two receptors was the biochemical consequences of receptor stimulation. Stimulation of the D-1 receptor enhanced the formation of CAMP; in the bovine parathyroid, a dopamine-enhanced formation of cAMP appeared to be involved in the physiological response to this amine (Brown et al., 1977, 1980). In contrast, stimulation of the D-2 receptor did not appear to enhance cAMP production; in the anterior pituitary gland, a dopamine-enhanced formation of cAMP did not appear to be involved in the physiological response to dopamine. This latter situation lead to the designation "cyclase linkage: No" for the D-2 receptor.

Since this hypothesis was put forward, several other investigators proposed the existence of as few as 1 or as many as 4 dopamine receptors (Laduron, 1983; Seeman, 1980; Sokoloff et al., 1980). The existence of these apparently conflicting classification schemata prompted testing of the validity of the two dopamine receptor hypothesis in three types of experiments. First, selective agonists and antagonists of the D-1 and the D-2 dopamine receptor have been identified in pharmacological experiments. Second, the consequences of stimulating the D-2 receptor have been determined in biochemical and physiological experiments. Third, binding assays have been developed which

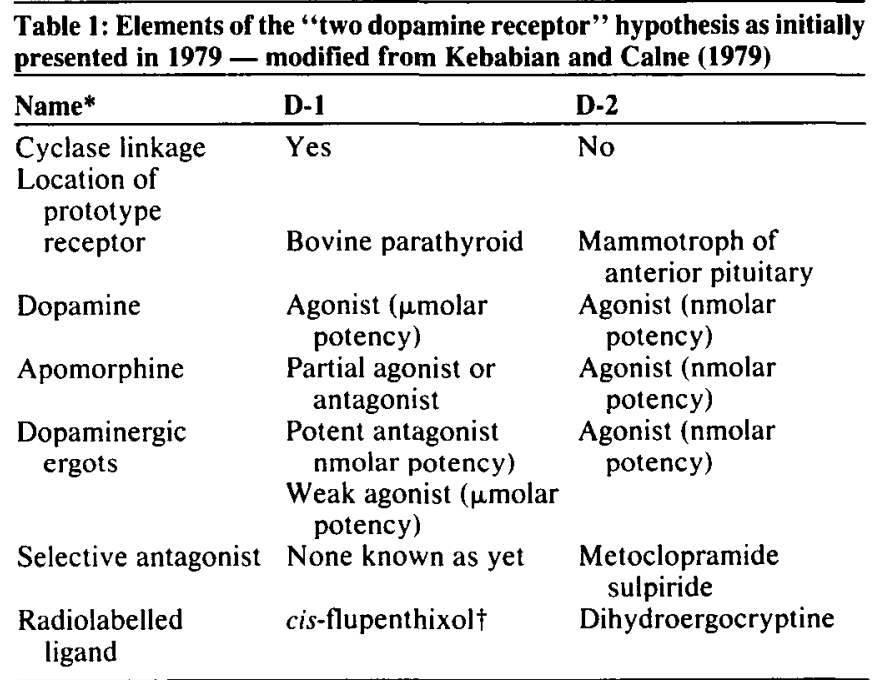

* Previously, the two categories of dopamine receptors were designated as ' $\alpha$-dopaminergic' and ' $\beta$-dopaminergic'. This has led to confusion with the $\alpha$ and $B$ adrenoreceptors. The new designations should prevent further confusion.

†Radiolabelled cis-flupenthixol can be used as a ligand specific for the dopamine receptor linked to adenylyl cyclase in the rat striatum. Its affinity for the dopamine receptor in the anterior pituitary has not been measured. 
are capable of identifying either the D-1 or the D-2 dopamine receptor. Data supporting the validity of the 'two dopamine receptor' hypothesis has been obtained from each of these endeavors.

\section{Selective D-1 and D-2 Agonists and Antagonists}

The development of stereoselective agonists and antagonists discriminating between the D- 1 and the D-2 dopamine receptors has provided pharmacological verification of the two dopamine receptor hypothesis. Several drugs selective for the $D-1$ receptor have come from the benzazepines (Figures 1 and 2). The first selective D-1 agonist, SKF 38393, was developed by Smith Kline and French Laboratories (Setler et al., 1978). The two optical isomers of SKF 38393 have been synthesized and their pharmacological activity evaluated. The D-1 agonist activity resides in the $(R)$-isomer; the $(S)$-isomer is significantly less potent (Kaiser, 1983). Recently, another selective D-1 agonist, designated as SKF 82526, has been synthesized as a potential antihypertensive agent (Hahn et al., 1982). Furthermore SCH 23390, the 7-chloro, $\mathrm{N}$-methyl analogue of SKF 38393, has been identified as a selective antagonist of the D-1 receptor (Iorio et al., 1983; Hyttel, 1983). In addition, SKF 83509, the 7-chloro analogue of SKF 38393, also selectively blocks the D-1 receptor (Itoh, Beaulieu and Kebabian, in preparation). The D- 1 antagonist activity of both molecules is a consequence of the 7-chloro substituent which diminishes the efficacy of the compound as an agonist and increases the affinity of the molecule towards the D-1 receptor (Itoh, Beaulieu and Kebabian, in preparation).

Several compounds have been identified as selective agonists upon the D-2 receptor. Both LY 141865 as well as RU 24926 mimic the effect of dopamine upon the D-2 receptor in the pituitary gland. However, neither of these compounds mimic

D-1

\begin{tabular}{|l|l|l|}
\hline $\begin{array}{l}\text { Adenylate } \\
\text { Cyclase }\end{array}$ & Enhances & $\begin{array}{l}\text { Inhibits } \\
\text { or } \\
\text { No effect }\end{array}$ \\
\hline Example & $\begin{array}{l}\text { Bovine Parathyroid } \\
\text { Neostriatum }\end{array}$ & $\begin{array}{l}\text { Pituitary gland } \\
\text { Autoreceptor }\end{array}$ \\
& $\begin{array}{l}\text { Cholinergic } \\
\text { Interneurons }\end{array}$ \\
\hline Agonist & SKF 38393 & $\begin{array}{l}\text { LY 141865 } \\
\text { RU 24926 }\end{array}$ \\
\hline Antagonist & SKF 83509 & $\begin{array}{l}\text { YM 90151-2 } \\
\text { Domperidone } \\
\text { (-) Sulpiride }\end{array}$ \\
\hline
\end{tabular}

Figure 1 - Elements of the "two dopamine receptor" hypothesis as of 1983. The most salient feature is the identification of the "first generation" of selective agonists and antagonists for the two categories of dopamine receptor. the ability of dopamine to stimulate adenylate cyclase; therefore, these compounds represent the selective D-2 agonists (Euvrard et al., 1980; Tsuruta et al., 1981). Recently, the structure of the active isomer of LY 141865 has been identified (Titus et al., 1983). There are many antagonists which selectively block the D-2 receptor. Both domperidone and YM-09151-2 are significantly more potent antagonists of the D-2 receptor than is (-)-sulpiride (Denef and Follenbouckt, 1978; Grewe et al., 1982).

The compounds identified in figure 1 are the 'first generation' of selective dopaminergic drugs. Their existence provides support for the validity of the 'two dopamine receptor' hypothesis. In addition, these compounds permit the identification of the structural features responsible for their selective properties. It seems reasonable to anticipate that additional agents possessing a higher degree of selectivity will be developed in the future.

\section{Consequences of stimulating the $\mathrm{D}-2$ receptor}

The pituitary gland has provided a biochemical model of the D-2 receptor. Using tissue of the intermediate lobe of the pituitary gland, stimulation of the D-2 receptor has been shown to diminish adenylate cyclase activity; this dopaminergic inhibition of
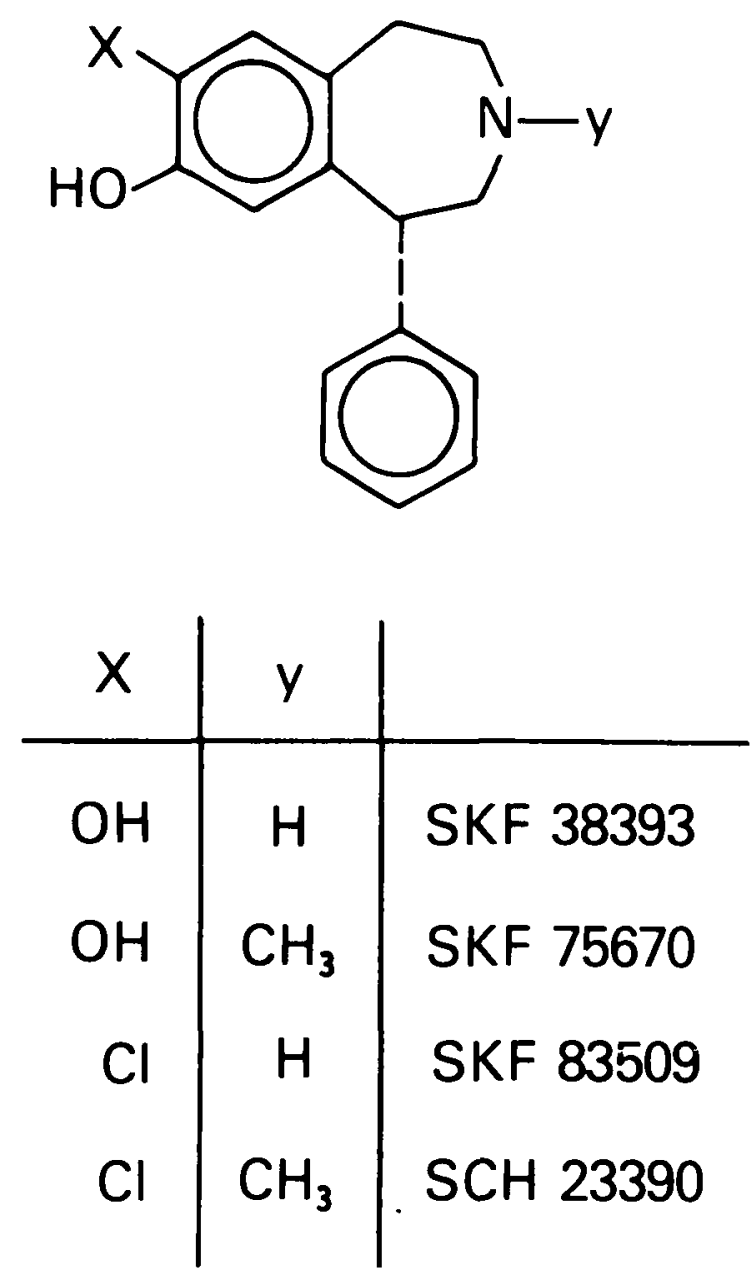

Figure 2 - Structure of several selective D-I agonists and antagonists. Both SKF 38393 and SKF 75670 are agonists upon the D-I receptor. In contrast, both the 7-chloro-substituted benzazepines are antagonists of the $D-1$ receptor. 
adenylate cyclase requires the presence of GTP in the enzyme assay system (Cote et al., 1982). The inhibitory effect of dopaminergic agonists is especially pronounced when the enzyme activity is enhanced with a stimulatory agent such as isoproterenol, cholera toxin, corticotropin releasing factor or forskolin (Cote et al., 1982; Meuniere and Labrie, 1982; Meuniere et al., 1982; Miyazaki et al., 1984). In the anterior pituitary gland, a similar dopaminergic inhibition vasoactive intestinal peptide-stimulated adenylate cyclase activity been demonstrated (Onali et al., 1981).

An example of D-2 receptor inhibiting adenylate cyclase activity has been identified in the central nervous system. In the neostriatum of the rat brain, D-2 agonists inhibit the efflux (and by inference, the synthesis of cAMP from intact tissue (Stoof and Kebabian, 1981, 1982). However, the anatomical complexities of the brain limits the precision with which the biochemical consequences of stimulating the receptor can be identified.

Three physiological consequences of stimulating the D-2 receptor in the intermediate lobe of the rat pituitary gland have been identified. Stimulation of this receptor decreases: the synthesis of cyclic AMP(Munemura et al., 1980); the spontaneous regenerative electrical activity across the plasma membrane (Douglas and Taraskevich, 1978, 1980, 1982); and the release of alpha-melanocyte stimulating ( $\alpha \mathrm{MSH}$ ) -like peptides (Munemura et al., 1980; Meuniere and Labrie, 1982). The inhibition of cAMP production can be attributed to the inhibition of adenylate cyclase activity. However, the relative importance of diminished cAMP synthesis and the inhibition of electrical activity in producing the inhibition of $\alpha \mathrm{MSH}$-like peptides remains to be determined. On the one hand, Douglas and Taraskevich (1980, 1982) provide evidence suggesting that the dopaminergic inhibition of electrical activity could diminish the amount of calcium ions entering the melanotroph; this diminished entry of calcium would inhibit the release of hormone from the cells. On the other hand, agents either promoting the synthesis or inhibiting the breakdown of cAMP enhance the calcium-dependent release of hormones from the intermediate lobe (Munemura et al., 1980). However, since removal of calcium from the extracellular environment blocks the release of hormone but does not inhibit the synthesis of CAMP, it may be concluded the cAMP does not trigger the release of hormone (Tsuruta et al., 1982). Reuter (1983) has suggested that in the heart cAMP may promote the entry of calcium into the myocardium; it remains to be determined if this mechanism exists in the pituitary gland.

The data obtained from the pituitary gland and brain indicated that stimulation of the D-2 receptor diminishes the synthesis of cAMP. This evidence is in accord with the view that certain "physiological responses to dopamine seem not to involve either the stimulation of an adenylyl cyclase or the accumulation of intracellular cyclic AMP" (Kebabian and Calne, 1979). However, it is also clear that the designation "cyclase linkage: No" for the D-2 receptor (Table 1) is no longer appropriate. However, in the neostriatum, a D-2 receptor occurs upon the acetylcholine-containing neurons as well as upon the terminals of the dopamine-containing nigro-neostriatal neurons. Stimulation of these receptors inhibits the depolarization-induced release of either acetycholine or dopamine. There is no evidence to suggest that cAMP participates in either of these physiological responses (Stoof, 1983).

\section{Binding assays identifying the D-1 and D-2 dopamine receptors}

Numerous dopaminergic drugs, radiolabeled to high specific activity, have been developed for identifying dopamine receptors in binding assays. In order to account for the discrepancies obtained in binding assays using different ligands, the existence of as few as one or as many as four different dopamine receptors has been proposed (Laduron, 1983; Seeman, 1980; Sokoloff, 1980). However, an alternative interpretation of these differences has recently been formulated by Creese. Sibley et al. (1982) propose that the D-2 receptor in the pituitary gland exists in two interconvertible states displaying different properties in binding assays. Furthermore, Leff and Creese (1983) report that the D-1 receptor may also exist in two states. According to this interpretation, the four receptors seen in binding assays represent the two states of the D-1 and the D-2 receptors. In accord with this possibility, Hyttel (1983) has recently claimed to have identified the D-1 receptor in a binding assay.

\section{CONCLUSION}

The classification of dopamine receptors remains an area of controversy among different investigators. The 'two dopamine receptor' hypothesis has been subjected to extensive testing in the 5 years since its formulation. The data obtained in many laboratories can be most easily interpreted within the guidelines provided by this hypothesis.

\section{REFERENCES}

Brown EM, Carroll RJ, Aurbach GD (1977) Dopaminergic stimulation of cyclic AMP accumulation and parathyroid hormone release from dispersed bovine parathyroid cells. Proc. Natl. Acad. Sci. (USA) 74:4210-4213.

Brown EM, Attie MF, Reen S, Gardner DG, Kebabian JW, Aurbach GD (1980) Characterization of dopaminergic receptors in dispersed bovine parathyroid cells, Mol. Pharmacol. 18:335-340.

Cote TE, Grewe CW, Tsuruta K, Stoof JC, Eskay RL, Kebabian JW (1982) D-2 dopamine receptor-mediated inhibition of adenylate cyclase activity in the intermediate lobe of the rat pituitary gland requires GTP. Endocrinology 110:812-819.

Denef C, Follenbouckt J-J (1978) Differential effects of dopamine antagonists on prolactin secretion from cultured rat pituitary cells, Life Sci. 23:431-436.

Douglas WW, Taraskevich PS (1978) Actions potentials in gland cells of rat pituitary pars intermedia: inhibition by dopamine, an inhibitor of MSH secretion, J. Physiol (London) 285:171-184.

Douglas WW, Taraskevich PS (1980) Calcium component to action potentials in rat pars intermedia cells. J. Physiol. (London) 309:623-630.

Douglas WW, Taraskevich PS (1982) Slowing effects of dopamine and calcium-channel blockers on frequency of sodium spikes in rat pars intermedia cells, J. Physiol. (London) 326:201-211.

Euvrard C, Ferland L, Di Paolo T, Beaulieu M, Labrie F, Oberlander C, Raynaud JP, Boissier JR (1980) Activity of two new potent dopaminergic agonists at the striatal and anterior pituitary levels, Neuropharmacology 19:379-386.

Grewe CW, Frey EA, Cote TE, Kebabian JW (1982) YM-09151-2: A potent antagonist for a peripheral $\mathrm{D}_{2}$-dopamine receptor. European J. Pharmacol. 81:149-152.

Hahn RA, Wardell JR, Sarau HM, Ridley PT (1982) Characterization of the peripheral and central effects of SK \& F 82526, a novel dopamine receptor agonist. J. Pharmacol. Exp. Ther. 223:305-313.

Hyttel J (1983) SCH 23390 - The first selective D-1 antagonist. European J. Pharmacol. 91:153-154.

Iorio LC, Barnett A, Leitz FH, Houser VP, Korduba CA (1983) SCH 23390 , a potential benzazepine antipsychotic with unique interactions on dopaminergic systems. J. Pharmacol. Exp. Ther. 226:462-468. 
Kaiser C (1983) Stereoisomeric probes of the dopamine receptor. In: Dopamine Receptors, American Chemical Society Symposium Series 224 (Kaiser C and Kebabian JW, eds.), American Chemical Society Press, Washington, pp. 223-246.

Kebabian JW and Calne DB (1979) Multiple receptors for dopamine. Nature 277: 93-96.

Kebabian JW, Calne DB, Kebabian PR (1977) Lergotrile mesylate: An in vivo dopamine agonist which blocks dopamine receptors in vitro. Communications in Psychopharmacol. 1:311-318.

Laduron PM (1983) Commentary: Dopamine-sensitive adenylate cyclase as a receptor site, In: Dopamine Receptors (Kebabian JW and Kaiser C, eds.), American Chemical Society Symposium Series 224, American Chemical Society Press, Washington, D.C., pp. 22-28, 1983.

Leff SE, Creese I (1983) Dopamine receptors re-explained. Trends in Pharmacological Sci., in press.

Meunier H, Labrie F (1982) The dopamine receptor in the intermediate lobe of the rat pituitary gland is negatively coupled to adenylate cyclase. Life Sci. 30:963-968.

Meunier H, Lefevre G, Dumont D, Labrie F (1982) CRF stimulates alpha-MSH secretion and cyclic AMP accumulation in rat pars intermedia cells. Life Sci. 31:2129-2135.

Miyazaki K, Goldman ME, Kebabian JW (1984) Forskolin stimulates adenylate cyclase activity, adenosine $3^{1}, 5^{1}$ monophosphate production and peptide release from the intermediate lobe of the rat pituitary gland. Endocrinology: in press.

Munemura M, Eskay RL, Kebabian JW (1980) Release of $\alpha$-melanocytestimulating hormone from dispersed cells of the intermediate lobe of the rat pituitary gland: involvement of catecholamines and adenosine $3^{1}, 5^{1}$-monophosphate. Endrocrinology 106:1795-1803.

Onali P, Schwartz JP, Costa E (1981) Dopaminergic modulation of adenylate cyclase stimulated by vasoactive intestinal peptide in anterior pituitary. Proc. Natl. Acad. Sci. (USA) 78:6531-6534.

Pieri L, Keller HH, Burkard W, DaPrada M (1978) Effects of lisuride and LSD on cerebral monoamine systems and hallucinosis. Nature 272:278-280.

Seeman P(1980) Brain dopamine receptors, Pharmacol. Rev. 32:229-313.
Reuter H (1983) Calcium channel modulation by neurotransmitters, enzymes and drugs. Nature 301:560-574.

Setler PE, Sarau HM, Zirkle CL, Saunders HL (1978) The central effects of a novel dopamine agonist, Eur. J. Pharmacol. 50:419-430.

Sibley DR, DeLean A, Creese I (1982) Anterior pituitary dopamine receptors. Demonstration of interconvertible high and low affinity states of the D-2 dopamine receptor. J. Biol. Chem. 257:6351-6361.

Sokoloff P, Martes MP, Schwartz JC (1980) Three classes of dopamine receptor (D-2, D-3, D-4) identified by binding studies with ${ }^{3} \mathrm{H}$-apomorphine and ${ }^{3} \mathrm{H}$-domperidone. Nauyn-Schmiedebergs Arch. Pharmacol. 315:89-102.

Stoof JC (1983) Dopamine receptors in the neostriatum: Biochemical and physiological studies, In: Dopamine Receptors, American Chemical Society Symposium Series 224 (Kaiser C and Kebabian JW, eds.), American Chemical Society Press, Washington, pp. $117-145$

Stoof JC, Kebabian JW (1981) Opposing roles for D-1 and D-2 dopamine receptors in efflux of cyclic AMP from rat neostriatum. Nature 294:366-368.

Stoof JC, Kebabian JW (1982) Independent in vitro regulation by the D-2 dopamine receptor of dopamine-stimulated efflux of cyclic AMP and $\mathrm{K}^{+}$-stimulated release of acetycholine from rat neostriatum, Brain Res. 250:263-270.

Titus RD, Kornfeld EC, Jones ND, Clemens JA, Smalstig EB, Fuller RW, Hahn RA, Hynes MD, Mason NR. Wong DT, Foreman MM (1983) The resolution and absolute configuration of an ergolinerelated dopamine agonist, trans-4, 4a, 5, 6, 7, 8, 8a, 9-octahydro-5propyl-1H (or $2 \mathrm{H}$ )-pyrazolo [3, 4-g] quinoline, J. Med. Chem. 26:1112-1116.

Tsuruta K, Frey EA, Grewe CW, Cote TE, Eskay RL, Kebabian JW (1981) Evidence that LY-141865 specifically stimulates the D-2 dopamine receptor. Nature 292:463-465.

Tsuruta K, Grewe CW, Cote TE, Eskay RL, Kebabian JW (1982) Coordinated action of calcium ion and cyclic adenosine $3^{\prime}, 5^{\prime}$ monophosphate upon the release of $\alpha$-melanocyte stimulating hormone from the intermediate lobe of the rat pituitary gland. Endocrinology 110:1133-1140. 